\title{
Challenging the Adaptationist Paradigm: Morphogenesis, Constraints, and Constructions
}

\section{Marco Tamborini ${ }^{1}$}

Published online: 12 May 2020

(C) The Author(s) 2020

\begin{abstract}
In this paper, I argue that the German morphological tradition made a major contribution to twentieth-century study of form. Several scientists paved the way for this research: paleontologist Adolf Seilacher (1925-2014), entomologist Hermann Weber (1899-1956), and biologist Johann-Gerhard Helmcke (1908-1993) together with architect Frei Otto (1925-2015). All of them sought to examine morphogenetic processes to illustrate their inherent structural properties, thus challenging the neoDarwinian framework of evolutionary theory. I point out that the German theoretical challenge to adaptationist thinking was possible through an exchange and transfer of practices, data, technologies, and knowledge between biologically oriented students of form and architects, designers, and engineers. This exchange of practices and knowledge was facilitated by the establishment of two collaborative research centers at the beginning of the 1970s. Hence, by showing the richness of topics, methods, and technologies discussed in German-speaking morphology between 1950 and the 1970s, this paper paves the way to a much broader comprehension of the shifts that have shaped twentieth-century evolutionary biology.
\end{abstract}

Keywords Morphology · Morphogenesis · Frei Otto · Adolf Seilacher · JohannGerhard helmcke · Organicism · Knowledge transfer · Architecture · Evo-devo · German synthesis $\cdot$ Form $\cdot$ Technology

Marco Tamborini

marco.tamborini@tu-darmstadt.de

1 Institut für Philosophie, Technische Universität Darmstadt, Karolinenplatz 5, 64289 Darmstadt, Germany 
Early in 1971, German paleontologist Adolf Seilacher (1925-2014) invited American paleobiologists Stephen Jay Gould and Dave Raup to Tübingen to give a short presentation at the first roundtable at the new Collaborative Research Center 53 $\left(\mathrm{SFB}^{1} 53\right)$ on paleoecology. Over two days, fifty paleontologists and biologists discussed how to combine paleontology with biology, morphology, and stratigraphy.

Gould was thrilled by this encounter and eager to communicate the topics discussed in Tübingen to his fellow American biologists. On March 16, 1971, he wrote to American paleontologist Gary N. Lane (1930-2006), co-editor of the Journal of Paleontology from 1969 to 1971, to express his excitement. Gould shared a short report with Lane on the meeting he had just attended in Tübingen. In the accompanying letter, Gould wrote, "I don't know whether the J. P. [Journal of Paleontology] usually publishes reports of paleontological meetings, but Dave Raup and I felt that Seilacher's meeting was so successful and unusual, both in the form and content, that American paleontologists would benefit learning about it and perhaps even acquire some suggestions for a similar gathering here."2

Lane recognized the importance of this meeting and eventually decided to publish Gould's report without any changes. In his two-page account, Gould sketched the "fresh ideas and procedures of the Tübingen meeting." In particular, he emphasized the "unorthodoxy" of the gathering because of the German biologists' "reluctance to grant Darwinian processes a complete role in the explanation of form." Specifically, Gould noted that while Germans were happy to admit natural selection a central role, as reflected in "obvious adaptation to definite environments," they were unwilling to accept its central role in shaping "basic Baupläne." Thus, Tübingen biologists proposed to grasp organic form by means of what they called Konstruktionsmorphologie. ${ }^{3}$ Gould summarized this unorthodox German approach as follows: Konstruktionsmorphologie means what we include under "functional morphology plus causal analysis of what might be called the dynamic architecture of form" (Gould 1971b, p. 1042).

Raup himself acknowledged the significance of Seilacher and colleagues' approach to evolution in his contribution to the groundbreaking book, Models in Paleobiology, edited by American paleontologist Thomas J. M. Schopf (1939-1984) and published in 1972. In the chapter dedicated to morphology, Raup described the method of Konstruktionsmorphologie developed by Seilacher in detail, thereby disseminating it to the English-speaking public. Like Gould, Raup trumpeted this new development in morphology. For instance, he wrote,

\footnotetext{
${ }^{1}$ In the German university system, SFB, short for Sonderforschungsbereiche, "are long-term universitybased Collaborative Research Centres, established for up to 12 years, in which researchers work together within a multidisciplinary research programme. They allow researchers to tackle innovative, challenging, complex and long-term research undertakings through the coordination and concentration of individuals and resources within the applicant universities." https://www.dfg.de/en/research_funding/programmes/ coordinated_programmes/collaborative_research_centres/. Accessed 12 July 2019.

2 Stephen Jay Gould Papers, M1437, Box 800, Tübingen form, 16 March 1971, Department of Special Collections, Stanford University Libraries, Stanford, California.

${ }^{3}$ On the difficulties of translating the term Konstruktionsmorphologie see Bock (1991, p. 17), where he noted that the best translation of Konstruktionsmorphologie might be "engineering morphology.".
} 
at the present time, there is significant and vigorous activity in paleontological research going on in Germany. Much of this work is made possible by a sizable grant ("Sonderforschungsbereich 53") from the West German government, with the research being coordinated at Tübingen University under the direction of A. Seilacher. This German program is important partly because of its sheer size but more significantly because much of it involves approaches not now emphasized outside continental Europe. (Raup 1972, p. 29)

What were Gould and Raup so excited about, and did it come to anything? A possible preliminary answer to these questions can be obtained by looking at the paper Gould co-authored with evolutionary biologist Richard C. Lewontin in 1979. ${ }^{4}$ In their influential article in the main organ of the British scientific establishment, the Proceedings of the Royal Society of London, entitled "The Spandrels of San Marco and the Panglossian Paradigm-A Critique of the Adaptationist Programme," the two biologists criticized the agenda that had "dominated evolutionary thought in England and the United States," by which natural selection is seen as an "optimizing agent" (Gould and Lewontin 1979, p. 581). Adaptationists, they stated, tended to pose exclusively what-for questions, asking what form is for, and understood organisms' traits as features resulting from natural selection and optimized for the present function. ${ }^{5}$ Gould and Lewontin proposed a different perspective on evolution.

According to Gould and Lewontin, Baupläne (or body plans) are "constrained by phyletic heritage, pathways of development and general architecture" (1979, p. 581). From this point of view, "constraints themselves become more interesting and more important in delimiting pathways of change than the selective forces" (p. 594). The two authors praised Adolf Seilacher for having uncovered constraints that did not "arise from former adaptations retained in a new ecological setting" (p. 595) and, as Derek Briggs noted, they used Seilacher's figure of "divaricate patterns in bivalve mollusks as the only biological illustration in their paper" (Briggs 2017, p. 4). Furthermore, Gould and Lewontin admitted that while this different focus on evolutionary mechanisms was "long popular in continental Europe" (p. 581), it was almost entirely absent in Anglophone biology. Indeed, as Gould himself noted in the report during the 1971 meeting on form in Tübingen, "German thinking about form ... differs systematically from our own in some fundamental ways. In particular, there remains a reluctance to grant Darwinian processes a complete role in the explanation of form ... thus, there is a much greater willingness to speak of the non-adaptive nature of many structures" (Gould 1971b, p. 1042).

Gould and Lewontin's paper presents an interesting historical conundrum, one that deeply influenced the development of the twentieth-century science of form. How, namely, did an admittedly "German" approach to the science of form, notable for its ambivalence about—or even hostility to-what was at the time considered an orthodox Darwinian perspective, come to feature so prominently in a major

\footnotetext{
${ }^{4}$ On the genesis of this paper see, Sepkoski (2012).

5 It is important to note here that this notion of adaptationism is very distinct from what Gould described as mechanical efficiency during the late 1960s and early 1970s. On this distinction, see the Conclusion, below, as well as Dresow $(2017,2019)$.
} 
critique authored by two notable American biologists (and published in the flagship of the British scientific establishment)? The unlikely appearance of a "European" formalist approach to adaptation can only be understood by examining the basis for that school of thought during the 1960s and 1970s, investigating how it challenged Darwinian adaptive thinking and, ultimately, understanding how it found its way to Gould and English-speaking biologists.

This paper argues that German morphological tradition made a major contribution to the twentieth-century study of form. Several scientists paved the way for this research: paleontologist Adolf Seilacher (himself a former student of paleontologist Otto Schindewolf [1896-1971], known for developing the cyclical model of evolutionary development known as "typostrophism"); Seilacher's second doctoral advisor, entomologist Hermann Weber (1899-1956); and biologist JohannGerhard Helmcke (1908-1993). Along with these biologists, the architect Frei Otto (1925-2015), known for having designed the West German pavilion at the Montreal Expo in 1967 and the roof of the Olympic Arena in Munich in 1972, made significant contributions as well. This group sought to examine morphogenetic processes in order to illustrate their inherent structural properties, thereby challenging the neoDarwinian framework of evolutionary theory. By investigating the practices, data, and technologies used by German morphologists to uncover the importance of structural conditions and properties of biological materials (topological, architectural, geometrical, etc.) overlooked by adaptationist interpretations of form, I will show that, over the course of the twentieth century, advocates of the typological and idealistically oriented tradition were able to take advantage of, limit, and rethink both their idealistic past and their mistrust of Darwinian mechanisms of evolution. ${ }^{6}$

Surprisingly, this rethinking was possible thanks to an exchange and transfer of practices, data, technologies, and knowledge between biologically oriented students of form and architects, designers, and engineers. This exchange of practices and knowledge was supported by the establishment of two collaborative research centers at the beginning of the 1970s: the Tübingen Collaborative Research Center (SFB) 53 on paleoecology and the Stuttgart Collaborative Research Center (SFB) 64 on wide span surface structures. These centers provided the necessary infrastructure and financial support to allow knowledge to flow, thus supporting disciplinary flexibility. As a result, this article can be seen as a preliminary essay towards an alternative history of evolutionary theory that, despite developing parallel to the Anglophone tradition itself, can be seen to have resonances in evolutionary developmental biology. ${ }^{7}$

\footnotetext{
${ }^{6}$ On the relationship between typological comparative anatomy, evolutionary morphology, and evolutionary innovation, see also Love (2003).

${ }^{7}$ I am currently preparing a book-length account of this so-far neglected history: The Architecture of Evolution: The Science of Form in Twentieth-Century Evolutionary Biology (under contract with University of Pittsburgh Press).
} 


\section{Situating "an Incorrect Perspective" on Form}

In order to understand how the "unfairly maligned" German "approach to evolutionary form," as Gould and Lewontin put it (1979, p. 159), was received and eventually introduced into mainstream English-speaking biology, we need first to focus on what happened in Germany between the late 1960s and the early 1970s. ${ }^{8}$

In post-World War II Germany, ${ }^{9}$ morphology found a fecund terrain. ${ }^{10}$ A majority of biologists conducted phylogenetic investigations and sought to bring together morphology, phylogeny, and evolutionary theory, as Carl Gegenbaur (1826-1903) had suggested (Nyhart 1995; Rieppel 2016). Biologists harshly criticized any idealistic approach to morphology, as can be seen in Die Evolution der Organismen (1943), the volume edited by biologist Gerhard Heberer and considered by many to be the most significant outcome of the so-called German synthetic theory of evolution. ${ }^{11}$ Conversely, they promoted a close connection between morphology and phylogeny. Further, they suggested that morphological research should necessarily be based on the identification of possible homologies.

Zoologist Adolf Remane (1898-1976) guided the postwar German generation of biologists who were keen to pair homology with morphology. Remane maintained a strong definition of what morphology was supposed to be. In his opinion, the discipline should not investigate the geometrical and quantitative relationships between different forms, ${ }^{12}$ nor should it inquire into how organs may accomplish specific tasks. Rather, according to Remane, morphology "pertains to the area of identity investigation" (1955, p. 163). By pointing out possible identities between organic forms, Remane believed that morphology needed to be "comparative' from the very outset" (1955, p. 164). To successfully separate the essential similarities from the unessential ones, morphologists needed to identify different types that may provide a certain stability for recognizing similarities and identity between forms. However, Remane's idea was not to simply revive the early twentieth-century idealistic notion of morphology; rather, he sought to better define the fundamental notion of homology and thus to firmly ground phylogenic morphology. Therefore, he noted, "by establishing a type, morphology seeks a specific match: homology" (Remane 1955, p, 169). He then identified several criteria to recognize unequivocally and indubitably two characters as homologues. As a result, Remane described the goal of phylogenetic morphology as the identification of "homologous correspondences,

\footnotetext{
${ }^{8}$ This is only one chapter in the broader history of twentieth-century morphology. Insights into nonGerman speaking morphologists can be found, for instance, in Love (2003).

${ }^{9}$ On the social and political situation of post-World War II German biology, see Rieppel (2016), Reif (1983, 1986), Levit (2006), Levit et al. (2014), Tamborini (2016), and Heumann et al. (2018). When I speak of German community in this paper, I mean both West German and GDR scientists.

${ }^{10}$ Morphological investigations played an important role in nineteenth- and early twentieth-century German-speaking biology. On this research and its roots in Goethe's writings, see Richards (2008), Richards (2002), Nyhart (1995), and Gliboff (2008).

${ }^{11}$ On the so-called German synthetic theory of evolution, see Princehouse (2003), Reif $(1983,1986)$, and Levit et al. (2014).

${ }^{12}$ For an analysis of quantitative morphology and systematics during the early twentieth century, see Tamborini $(2015,2019 b)$.
} 
on whose distribution the natural system and, at the same time, the systematic type and the pure stem form [in the sense of ancestor] are - simply and clearly - based"13 (Remane 1952, p. 163). As Olivier Rieppel has summarized, Remane's Die Grundlagen des Natürlichen Systems, der vergleichenden Anatomie und der Phylogenetik (1952) was a "treatise on the principles of comparative anatomy, systematics, and phylogeny reconstruction can in some way be thought of as a continuation of Gegenbaur's program in systematic or phylogenetic morphology, revealing further influences from Sinai Tschulok and Adolf Naef” (Rieppel 2016, p. 209).

Furthermore, paleontology —one of the most classical morphological disciplines in Germany-was dominated by Otto Schindewolf's theoretical analysis. In several publications, Schindewolf presented a cyclical theory called "typostrophism," in which the evolution of an individual lineage is divided into three different stages (Schindewolf 1936, 1950, 1964). The first stage, in which body plans appear very suddenly and explosively without any contribution of natural selection, is known as typogenesis. During the second stage, typostasis, changes occur slowly and are driven by an organism's intrinsic forces (that is, they are orthogenetically directed). Here the transition of types from one class to another is possible. The last phase is typolysis. This phase is characterized by the decline of taxa due to a kind of evolutionary senescence. Reif noted that Schindewolf's theory was unique because it combined orthogenesis, saltationism, and cyclism: "Like the cycle of individual development from youth to old age, taxa on all levels arise by spontaneous saltations. They have a life cycle of (1) spontaneous diversification; (2) elaboration and finally (3) degeneration, which leads to extinction" (Reif 1993, p. 447).

Due to the obvious incompatibility of typostrophism with the Darwinian evolutionary account, there was significant friction between the North American and Neo-Darwinian-oriented biological communities and several German biologists. As Marjorie Grene compellingly showed, the concept of morphology lay at the center of these significant disagreements (1958). ${ }^{14}$

It is in this context that Seilacher invited Gould and Raup to Tübingen. Although postwar German morphology seemed to be governed by phylogenetic analysis, the emphasis Seilacher and his colleagues placed on the structural and dynamic elements of form was the end result of a combination of methods and approaches to morphogenesis that had long been present in German-speaking biology. Seilacher can and indeed should be remembered as a great synthesizer. He was able to bring together different approaches to organic form that had developed during the 1950s and combine them into a unified working method in the late 1960s. This transition, though, would not have been possible without the theoretical framework offered

\footnotetext{
13 Translation in Richter (2016).

14 As Grene famously wrote, "Simpson argues: the neo-Darwinian theory is true; morphology implies that neo-Darwinism is not true; therefore morphology is wrong. Schindewolf argues: morphology must first be accepted as true; morphology implies that the neo-Darwinian theory is wrong; therefore the neoDarwinian theory is mistaken. Or to put the matter another way, they agree on their major premiss: traditional morphology and neo Darwinism are incompatible. One says: Darwinism; therefore not morphology; the other says: morphology, therefore not Darwinism" (1958, p. 116). On twentieth-century German paleontology, see Tamborini (2016, 2017), Reif (1983, 1986).
} 
by Seilacher's second doctoral advisor, the German entomologist Hermann Weber (1899-1956).

\section{"Enough: The Knot Is Indissoluble; Let's Cut It": Organic Form as Construction}

The term Konstruktionsmorphologie was originally coined in the early 1950s by Seilacher's second doctoral advisor, Hermann Weber. Weber had a lasting, although sometimes overlooked, impact on the development of twentieth century morphology. ${ }^{15}$ Following his studies at and doctorate from the University of Tübingen, Weber held several teaching positions at the Universities of Münster, Freiburg, and Vienna before returning to Tübingen, where he directed the Institute of Zoology from 1951 to 1956 . In several publications, he worked towards establishing a new methodological basis for twentieth-century morphology so the discipline could leave behind its descriptive method and thus finally compete with experimental biology.

Weber's point of departure was his belief that morphology needed a complete "revision" in order to escape from the "labyrinth of personal opinions" (Weber 1958, p. 22) and avoid the dichotomy between typological and functional morphology that had characterized early twentieth-century evolutionary biology. He thus decided to make a radical move. He had noticed that the main morphological concepts were not clearly defined. Generally, morphologists used expressions derived from a "psychological, historical, physical, chemical, and technical terminology" that generated major "conceptual confusion" (p. 46). Therefore, it was quite impossible to use morphological concepts properly and unambiguously. Weber thus announced: "enough: the knot is indissoluble; let's cut it!" (p. 47). Weber decided to cut the Gordian knot that had forcefully tied together the main morphological concepts over the last decades and redefine them completely. "In case of doubt," wrote Weber, "in biology, form ... can be replaced with architecture" (p. 47). More precisely, Weber distinguished architecture, plan [Bau], and construction [Konstruktion] as mutually informing concepts to describe organic form. As Weber wrote,

Plan $[\mathrm{Bau}]$, adjective "structural" [baulich]. A word that, in all its confusion, has been worthy of note. I use it only for the field of biology and understand by it the spatial behavior of the parts constituting an organic structure, including their mutual spatial relationships, their material character, strength, coloring, and drawing. (Weber 1958, p. 48)

Yet, since the pure external investigation of organisms uncovers their external features, by considering the "functional and effective nature of the plan [Bau]," one arrives at the very concept of construction [Konstruktion]. This "is a significant and crucial extension of the classical morphological analysis" (p. 48), for morphologists could now focus on how the structural elements of plan are held together as well as how they work collectively.

${ }^{15}$ On Weber, see Rieppel (2016), Maier (2008), and Reif (1985). 
Having re-defined several basic morphological concepts, Weber explained his own research program at length. He clearly defined its future tasks and stated that constructional morphology [Konstruktionsmorphologie]:

starts from the pure plan and its development [Bau und seinem Werden]. It expands itself on the construction [Konstruktion] and its dynamics, on the development of the construction [Konstruktion] and on the dynamics of this becoming in the ontogenesis, in the generation process and in the evolution. Beginning with the extension of its investigations to construction [Konstruktion] and thus to adaptation and co-adaptation, it seeks to understand its object under the dual aspect of autonomy and dependence on the environment. It seeks to make plan $[\underline{\mathrm{Bau}}]$ understandable through the analysis of construction [Konstruktion] and the systematic order of evolution. Morphology's ultimate goal is the adequate representation of the organizations in space and in time, including their dynamics, emphasizing though the vivid and ... relatively constant ... construction and construction systems." (Weber 1950/1951, p. 135) ${ }^{16}$

Hence, the morphologist's main task was to represent adequately the genesis and constructional elements of organisms. To achieve this aim, Weber proposed bringing together all the different and sometimes contrasting approaches to organic form so far developed. However, his aim was to transcend them all: "I see the goal of my synthesis of constructional morphology in overtaking [Überholen] the previous approaches. 'Overtaking' is here understood in both senses of the word, as leaving behind [Zurücklassen] the no longer suitable and as a renewal [Erneuerung] of what is still usable under further uses" (Weber 1958, p. 30).

As a result, Weber defined construction morphology as the connection between the "ecological, constructional and physical-physiological aspects." In so doing, he stressed the impossibility of grasping complex constructions from a single point of view. Organisms were indeed conceived as complex constructions:

Neither of the two morphological directions cited above, and thus no morphology in the previous sense of the word, is capable of grasping the organism as a form in the most comprehensive sense of the word, as a historically developed space-time system [den Organismus als Gestalt im umfassendsten Sinne des Wortes, als historisch gewordenes Raumzeitsystem]. (Weber 1958, p. 69)

Thus, Weber emphasized a synthetic approach to morphology able to move beyond the labyrinth of opinions and conflicts in early twentieth century morphology. Furthermore, his approach stressed the strong connection between form and construction. The morphologist's task was to investigate the functional and effective features of form. In fact, in 1954 Weber, speaking at the $48^{\text {th }}$ annual meeting of the German Zoological Society, proclaimed that "together with students and collaborators, [he had] taken up the realization of this program. This will be the central task of the Tübingen Zoological Institute" (Weber 1954, p. 155).

16 Translated by Wolf-Ernst Reif. See Reif 1985. 
Seilacher would use all these insights as a valuable methodological framework upon which to develop his own viewpoint on organic form. However, its role in influencing Seilacher's framework for theoretical morphology should not be overemphasized. Seilacher's early empirical works on paleoichnology were also extremely relevant in developing his own notion of Konstruktionsmorphologie.

\section{Form as Animal Artifact}

The pressing problem for several biologists who were unwilling to embrace homology fully as the only guiding principle in morphology was to identify an alternative standpoint on form. ${ }^{17}$ This issue was even more persistent in paleontology, which often had access only to the final product of what was inferred to be a series of intermediate forms. Furthermore, function usually had to be inferred from organismal structure, since paleontologists (obviously) are unable to observe the behavior of the organisms they study.

However, in the mid-twentieth century a fairly marginal paleontological sub-discipline witnessed an unexpected renaissance. Paleoichnology, or the study of trace fossils (for example, footprints or movement tracks preserved in sediment) became highly relevant in assisting paleontologists to determine form from structures. ${ }^{18}$ The challenges paleontologists faced in this discipline were of a purely morphological nature: they struggled to understand how it was possible to deduce from a readymade trace its possible producer. Paleoichnology attempted to address this problem and, more broadly, to investigate evolutionary patterns in the development of form.

In his 1951 dissertation, Seilacher addressed this classical morphological problem. He sought a reliable method to classify, read, and eventually interpret the enigmatic meaning of trace fossils. In a series of papers based on his thesis, Seilacher proposed several methodological approaches to disentangle this issue. According to Seilacher, the relationships that hold together several structural features of form were primarily taxonomic, ecological, and sedimentological.

From a taxonomic point of view, trace form depends on the physical organization of its producer (Seilacher 1953a). Seilacher admitted that this approach had only limited validity, since phylogenetically related species often produce traces that are very distant according to their exterior features. Traces could also be studied from an ecological point of view. From this perspective, form appeared as a "product or as an independent carrier of a biological function" (Seilacher 1953a, p. 432). Here, Seilacher understood "biological function" to mean very basic biological needs, such as "housing, nutrition, locomotion" (1953a, p. 432). Using this approach, the paleoichnologist would no longer be "dependent on randomly obtained fingerprints, but [would] rely on more prominent features (outline, shape), so that the ecological interpretation can also be applied to poorly preserved or undifferentiated pieces"

\footnotetext{
17 For a different and more quantitative solution to this problem, see Olson and Miller (1958), Love (2003), and Tamborini (2019b).

18 On the history of invertebrate ichnology, see Osgood (1975).
} 
(1953a, p. 435). Thus, an "ecological" reading was essential since it provided the morphologist with an accurate method to work with and interpret her/his data. Furthermore, the ecological meaning of the traces' characteristics were usually "directly apparent because they resemble well-known technical principles (i.e. the analogy of branched crawler lane [Kriechspur] to road network, meandering track to mower track, Rhizocorallium or Chondrites to hard coal mining [Steinkohlenbergbau]!)" (1953a, p. 435). In other words, trace fossils could sometimes be interpreted by analogy to products of human technology.

Finally, trace fossils could be evaluated through a sedimentological analysis. In this case, the shape of a trace emerged as the specific response of the physical substrate to a possible mechanical deformation. A trace may emerge, disappear, or be deformed due to the physical and chemical features of different substrates. Tracefossil shapes therefore depend also on physical processes.

Although all of these three different readings were equally important to interpret the structural elements of form, only by combining the ecological with the mechanical perspective could the paleoichnologist obtain a stronger understanding of form. According to the unified mechanical-ecological approach, Seilacher noted,

the shape characteristics of many life traces (="animal artifacts"!) [(="tierische Artefakte!")] are primarily purpose-related [zweckbedingt]. They can therefore be directly understood not only by their causal relationship with the construction of their author [mit der Konstruktion ihres Urhebers], but also by their ecological and "technical" meaning (i.e. teleological) [ihre ökologische und "technische" Bedeutung (d.h. teleologisch)]. (1951, p. 279)

Seilacher identified trace-fossil forms as possible "animal artifacts." ${ }^{19}$ As purposerelated forms, they could be understood, in turn, by studying the external mechanisms and factors - for example, chemical, physical, ecological etc.- that may have produced them. Precisely as with any artifact, the materials' structural properties are essential to produce different forms.

As a result, during the 1950s Seilacher proposed a synthetic approach to organic form: the three approaches he identified-the taxonomic, the ecological, and the sedimentological interpretation-actually worked together in the investigations of a single track, without excluding each other. Indeed, as he put it, a "threefold interpretation of form is even desirable" to uncover a trace fossil's structural properties as well as to infer the broader causes of morphogenesis (Seilacher 1951a, p. 17).

In a 1950 letter to the German paleontologist Wilhelm Schäfer (1912-1981), Seilacher explained his evolving understanding of organic form. In commenting on one of Schäfer's papers, Seilacher wrote that "not only form and function were two manifestations of the same phenomenon," as Schäfer (1937) and Alfred Benninghoff (1890-1953) (1937) had already recognized, but also "that these coupled components should be considered together with the powerful role of environment." As a

19 Seilacher expanded the ideas of German paleontologist Rudolf Richter (see Richter [1927]). 
result, he argued, these elements should be studied as "an organic system." 20 Thus, in order to classify and interpret biological form, form has to be seen as the result of different and entangled processes. These are not isolated, but rather constitute an organic whole.

Throughout his 1950s publications (Seilacher 1951b, 1953a, 1953b), Seilacher began conceptualizing a visual system able to combine these three different approaches to form. In fact, in 1953, Seilacher wrote that form is "completely determined as a point in space by its coordinates x, y, and z" (Seilacher 1953a, p. 438). Eventually, he would export his methodological framework used to interpret trace fossils to the study all biological forms, embodied in the famous triangle diagram produced at the end of the 1960s (see Fig. 1).

\section{Morphogenetic Model: Organic Form Between Structural Constraints and Architectural Licenses}

As mentioned above, the January 1971 Tübingen meeting inaugurated the formal research activities at the newly established Collaborative Research Center (SFB) 53 on paleoecology. In his proposal submitted to the German Research Foundation (DFG) in 1968, Seilacher pointed out the necessity of an innovative collaborative project on morphology. He identified two main morphological directions in recent paleontology. On the one hand, based on functional morphology, researchers understood forms as adaptive and "convergent approximations [Annäherungen] to an ideal adaptive type (paradigm) and provided a teleological interpretation of their phylogenetic variations." ${ }^{21}$ On the other hand, morphologically oriented paleontology was used to fulfill geological and stratigraphic aims, such as classifying index fossils.

However, Seilacher noted that both the data and approaches of morphology were full of "errors and distortions." 22 Therefore, the SFB 53 aimed at investigating the limits of these data and exploring the possibility of a well-grounded paleontological interpretation of form. Specifically, its goal was to analyze "which adaptive route can be predetermined by a growth program [Wachstumsprogramm] and architectural engineering [Bautechnik]." ${ }^{23}$ The main focus of the collaborative research center was consequently to inquire into the "mechanisms behind pre-adaptive processes" 24 often overlooked by morphologists. Or, to put it differently, Seilacher's main intention was to investigate the laws of morphogenesis without engaging in the

\footnotetext{
${ }^{20}$ Letter to Wilhelm Schäfer, 8 January 1950. Institut für Stadtgeschichte Frankfurt am Main (ISG FFM), ISG_V176_05203.

21 UAT 596/3003, "Sonderforschungsbereich 53: Paläontologie unter besonderer Berücksichtigung der Palökologie ", p. 9.

22 UAT 596/3003, "Sonderforschungsbereich 53: Paläontologie unter besonderer Berücksichtigung der Palökologie ", p. 2.

23 UAT 596/3003, "Sonderforschungsbereich 53: Paläontologie unter besonderer Berücksichtigung der Palökologie ", p. 2.

24 UAT 596/3003, "Sonderforschungsbereich 53: Paläontologie unter besonderer Berücksichtigung der Palökologie “, p. 2.
} 
teleological thinking implied in an extreme emphasis on natural selection: forms can also be the product of non-adaptive mechanisms.

To accomplish this aim, Seilacher decided to harden the standpoint on morphology he had developed during the 1950s. Rhetorically, he identified Martin Rudwick's paradigm method as a scapegoat for a bad, teleologically-oriented approach to morphology (Rudwick 1964). Before becoming a well-known historian of science, Rudwick was trained and worked as invertebrate paleontologist at the University of Cambridge and, during the 1960s, had elaborated an important method to infer function from structure in fossils. ${ }^{25}$ Based on the idea of optimal or organic design developed by British biologist Carl Pantin (1899-1967) (Pantin 1951), Rudwick proposed approaching fossil structure as if it "might have been an adaptation to a particular function" and coming up with a method to find a possible model, or paradigm, "that would be capable of fulfilling the function with the maximal efficiency attainable under the limitations imposed by the nature of the materials" (1964, p. 36). The paradigm that is considered to be most related to the actual structure is regarded as the most probable. Rudwick's main conclusion was that "the detection of any adaptation in a fossil organism must be based on a perception of the machinelike character of its parts and on an appreciation of their mechanical fitness to perform some function in the presumed interest of the organism" (1964, pp. 34-35).

According to Seilacher, however, Rudwick's approach was centered merely on the power of natural selection. It emphasized only the adaptive meaning of organic forms. In this "necessarily teleological way of looking" at biological form, the "importance of adaptive changes is quite often overestimated." ${ }^{26}$ Indeed, Seilacher continued, "in reality every organismal form contains form-elements, which are first and foremost reducible to the architectural [bautechnisch] principles or to certain growth processes that can partly be mathematically simulated." Accordingly, he proposed to define constructional morphology as an attempt to "bring together functional and theoretical morphology." This future discipline would make the comprehension of body plans and their structural characters much more complete. First and foremost, though, constructional morphology would aim at "defining the limits within which adaptation and natural selection are effective." 27 Thus, in the official proposal submitted to the Deutsche Forschungsgemeinschaft (DFG), Seilacher emphasized the essential role of architectural elements in form-production in order to investigate the limits of adaptationist explanations of form. Architectural elements were often overlooked by mainstream biologists, who focused instead only on the power of natural selection as an optimizing agent.

The 1971 Tübingen meeting was the first public occasion at which Seilacher's proposal on Konstruktionsmorphologie was discussed. In his “Arbeitskonzept zur

\footnotetext{
25 On Rudwick's method and his years as invertebrate paleontologist, see his retrospective essays (2017, 2018).

26 UAT 596/3003, "Sonderforschungsbereich 53: Paläontologie unter besonderer Berücksichtigung der Palökologie “, p. 9.

27 UAT 596/3003, "Sonderforschungsbereich 53: Paläontologie unter besonderer Berücksichtigung der Palökologie “, p. 9.
} 
Konstruktions-Morphologie" [Working paper on Konstruktionsmorphologie] published in the journal Lethaia a year earlier, ${ }^{28}$ Seilacher had rethought the theoretical framework of the collaborative research centers sketched in his DFG proposal, extensively expanding it. Specifically, Seilacher took up Weber's overarching method and sought a way to both incorporate and transcend mainstream approaches to form. Form, Seilacher admitted, is certainly co-determined by "evolutionary heritage" as well as by "necessities of adaptation to specific environments," as Rudwick had pointed out (Seilacher 1970, p. 393). These approaches, however, can be seen only as two self-limiting factors in a three-element morphological framework. Here Seilacher introduced a third element: his ecological-mechanical approach to form. This suggested that forms were also the result of non-adaptive processes that depended on ecological and mechanical factors.

Thus, in his Arbeitskonzept, Seilacher elaborated on his 1950s framework and called attention to the dynamic aspects of form-construction (as Weber had put it). This would help him uncover further structural morphogenetic, that is, form-generating elements. As he put it, besides "inheritance and necessities of adaptation to specific environments, skeletal morphology seems also to be regulated by morphogenetic programs which often appear as non-adaptational elements of low taxonomic significance" (Seilacher 1970, p. 393).

Seilacher began developing the idea of morphogenetic programs in the early 1960s. In his understanding of the concept, a morphogenetic program describes "a program of commands such as might be written for a computer" able to self-produce and unfold particular forms (Seilacher 1967, p. 72). For instance, in order to investigate the structural and biological properties of complex three-dimensional tunnels produced by polychaete worms, "only two commands ${ }^{29}$ need to be added to the four commands that produce horizontal meanders." The first additional command is "after spiraling inward make a U-turn and keep in contact with the adjacent tunnel on the horizontal;" the second is "after spiraling outward turn down and keep in contact with the adjacent tunnel vertically" (Seilacher 1967, p. 76). As a result, the morphologist is able to explain these forms as animal artifacts produced according to a simple morphogenetic program. This program was dynamic enough to adapt itself to the physical and chemical features of the environment and produce suitable forms.

Through Seilacher's encounter with David Raup in the mid-1960s, the idea of non-adaptational morphogenetic programs was investigated at length by means of computers. In 1969, the two paleontologists co-authored a seminal paper in which they brought together Raup's computational experience with morphological simulations with Seilacher's ecological-mechanical approach to form to simulate theoretically possible morphogenetic processes (Raup and Seilacher 1969).

\footnotetext{
${ }^{28}$ This was a strategic decision since the journal published also English articles, thus reaching a much wider community.

29 These were, namely: "Move horizontally, keeping within a single stratum of sediment," and "after advancing one unit of length make a U-turn" (Seilacher 1967, p. 75).
} 
This joint project expanded on Raup's own investigation of morphogenesis. At the beginning of the 1960s, Raup identified four parameters responsible for coiled gastropod shells and used a "digital computer with automatic plotting equipment ... to make graphical reconstructions of a shell from any given values of the four parameters" (Raup 1962, p. 150). He then presented a hypothetical snail form simulated according to the four parameters previously identified. In this case, form resulted from growing-processes (Raup 1961, 1962, 1966, 1969; Raup and Michelson 1965). ${ }^{30}$

However, at the end of the 1960s Seilacher went a step further. He came up with a simple concept able to promote the idea of non-adaptive morphogenetic structures. In his Arbeitskonzept, he introduced the general category of "fabricational or architectural factors" (Seilacher 1970). He subsumed under this category all the elements responsible for form-production that could not easily be reduced to phylogenetic or adaptational processes. These do not merely constrain the power of natural selection-as, for instance, phylogenetic legacy does-but they also allow further evolutionary transformations. Indeed, Seilacher defined them as "architectural licenses" (Seilacher 1970), drawing an analogy to the ecological licenses introduced by German biologist Klaus Günther in 1949. The basic idea was that possible forms need to be "authorized" by materials' technical and architectural properties in order to further transform themselves. These properties permit the unfolding of particular forms and therefore should be treated as a complementary evolutionary mechanism, in addition to natural selection and mutations (Seilacher 1973). ${ }^{31}$

As Weber had observed, though, architectural elements were not sufficient to explain the dynamic and complex status of organic form. Organisms needed to be investigated as dynamic constructions from any possible point of view. Therefore, Seilacher added in his Arbeitskonzept the caveat that,

although architectural licenses [bautechnische Lizenzen] may merit special interest at the moment, they cannot be studied independently of more traditional perspectives on form. Rather, in each individual case, the scope of all form-determining factors has to be grasped and weighed against each other. For such a synopsis, the term "construction morphology" was adopted here, which has been introduced in the zoological field for years (see H. Weber 1955). (Seilacher 1970, p. 396)

As a result, Seilacher defined constructional morphology as a particular approach to form that "combines the phylogenetic, the adaptational, and the architectural aspects in the analysis of a given structure. Each structure may be understood as a

\footnotetext{
30 On Raup's theoretical morphology see Sepkoski (2012) and Tamborini (2019a).

31 As Seilacher and Alan D. Gishlick wrote in 2014, fabricational or architectural elements "owe their regularity primary not to a detailed genetic program, but to an extrinsic principle - be it mechanical, chemical, or biological in nature. This means that such 'self-organizing' morphogenetic mechanisms have a certain autonomy, as reflected in variabilities that remain beyond genetic control" (Seilacher and Gishlick 2014, p. 2).
} 


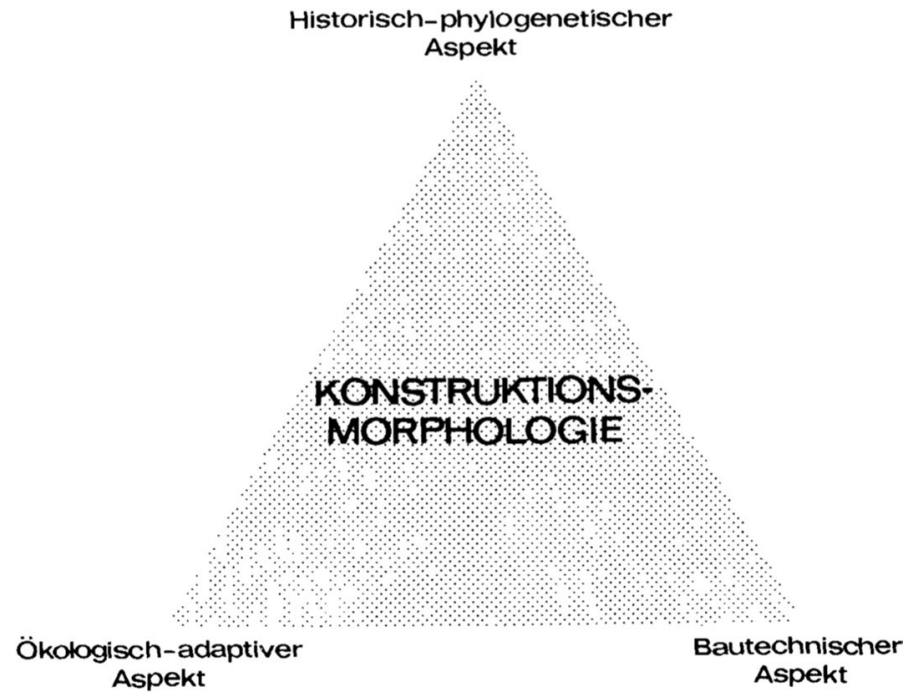

Fig. 1 Seilacher's Original Visualization of Constructional Morphology (Seilacher 1970). Reprinted with permission from Wiley

compromise between the criteria provided by the "Bauplan," paradigm, and architectural program" (Seilacher 1970, p. 394).

To better promote his idea, Seilacher eventually visualized these three important and reciprocally constraining elements as three corners of a triangle (Fig. 1). Form resulted, then, as a product of three self-limiting aspects.

\section{Stuttgart, 1971: Organic Forms and Lightweight Constructions}

Seilacher was not the only biologist who was theorizing organic form as the result of physico-chemical and mechanical constraints imposed by the properties of materials. During the 1960s and 1970s, a dynamic group of scientists focused on the possibility of understanding morphogenesis as the result of form's structural elements rather than as the unfolding of a detailed genetic program. Indeed, in parallel to the founding of the SFB 53, another research center was sponsored in Germany: the SFB 64 on wide span surface structures, that is, on structures which span more than 20 meters. This SFB was based in Stuttgart and divided into four subprojects. Among them, subproject B, guided by two architects, Frei Otto and Berthold Burkhardt, was dedicated to design principles.

German architect and structural engineer Frei Otto had started to investigate this topic during the period he spent as an architecture student in Berlin between 1948 and 1954. ${ }^{32}$ After a period of study in America in 1950, during which he met

$\overline{32}$ On Frei Otto, see Otto et al. (2005, 2017), Meissner and Möller (2015), and Keller (2018). 
leading proponents of organic architecture such as Frank Lloyd Wright and Richard Buckminster Fuller, Otto opened his studio in Berlin and also continued his studies at the Technical University, eventually earning his doctorate in tensioned constructions in 1954. Otto first gained international recognition in 1967, when "the leaders of Germany chose Otto's architecture to demonstrate the nation's post-World War II industrial and engineering expertise and innovative technologies. The resulting German pavilion at Expo 67, created in collaboration with Rolf Gutbrod and Fritz Leonhardt, gave Frei Otto his international breakthrough as an architect and a design engineer. It's an early example of a large scale, passive solar building." 33

It was through an encounter with the German biologist Gerhard Helmcke in 1961 that Otto began to dedicate himself to the relationship between biology and construction. Helmcke, a specialist in electron microscopic examinations of teeth and diatoms, began receiving international recognition in the 1950s for his discovery of the prismatic structure of tooth enamel. However, it was through his specular photogrammetric measurements of Diatoms and Radiolaria (Helmcke and Krieger 1953-1977) that he established an international following. Helmcke's description of these microorganisms led him to embark on several interdisciplinary endeavors. With Heinrich Hertel, professor of aeronautical engineering at the Technical University of Berlin, he set up a "marriage between engineering and biology," which led to the battle cry "TUB" [short for: Technologie und Biologie] (Hertel 1963). This working group aimed at investigating the structural properties of swimming oscillating objects.

During the same years, Helmcke accepted another important collaboration. In the winter semester of 1961/1962, Helmcke and Otto offered a joint course at the Technical University on "Biology and Building" and co-authored a paper based on the topic of their lectures. In this paper, Otto and Helmcke emphasized the strong relationship between living and technical constructions. As they wrote,

living constructions, by which the own inner constructive structure of plants and animals is to be designated here, often resemble so much the "technical constructions" of man that the question arises whether the likeness is accidental or whether laws are underlying. A random relationship appears almost impossible. In the case of living constructions, very specific construction principles can be pursued, which, however, occur in many variants. The similarity with the technical constructions relates less to the external shape than to the same constructive areas. (Helmcke and Frei 1962, p. 856)

The comparative investigation of living and technical constructions was also moved to the center of the sub-project B at the SFB 64. As had been the case for SFB 53, an initial workshop set the future agenda for this SFB. In the same year, in 1971, architects, engineers, and biologists met in Stuttgart to discuss the relationship between biology and building. The workshop was organized by Otto and Helmcke themselves and advertised as follows: "our recent work has shown that there are many points of

\footnotetext{
33 Biography: Frei Otto. Pritzer Architecture Prize. https://www.pritzkerprize.com/biography-frei-otto. Accessed 12.07.2019. Otto won the Pritzer Architecture Prize in 2015.
} 
contact between biology and building. When comparing forms and constructions in the fields of architecture, urban constructions, and biology, a plethora of questions arise: We ask about the relationship between the individual and the environment, about problems of behavioral psychology, paleontology, biomechanics, sociology etc." 34 To understand the morphogenetic principles behind organic and inorganic form, they explicitly decided to invite scientists who had already worked on the structural aspects of form. Along with Seilacher, they invited Wilhelm Schäfer, Paul Bühler, and Wolfgang Gutmann to contribute to the meeting. The workshop proceedings were later published in three issues of the journal of the Institute for Lightweight Structures (IL) (Institut für Leichte Flächentragwerke 1971, 1972, 1973). These journal issues provided remarkable insights into the structural approach to form developed in the late 1960s and early 1970s.

Otto's standpoint on the genesis and structure of form departed from the simple idea that architects' perspectives on this issue could assist biologists in identifying structural elements previously overlooked in morphogenetic processes. For example, at the 1971 meeting he asserted: "not only has biology become indispensable for building, but building for biology. A biologist with an eye trained by architecture can discover more in his biological objects" (Otto 1971, p. 9). This cooperation was aimed not only as a mere and "simple visual takeover of experienced forms," but it was grounded in the broader idea that "similar and even equivalent form generating processes" occurred in biology and building. Indeed, Otto added, "there are fundamental relationships between the technical and biological selection processes" (Otto 1971, p. 9) that could be investigated in-depth.

Yet, although mutation and selection are important biological mechanisms, the architectural perspective drew attention to another significant aspect of form production: its efficiency. In biology, the study of form efficiency was the task of functional biology. In order to be efficient, a biological form had to fulfill a particular function optimally. Otto interpreted this classical functional notion differently. In line with the definition given by American architect Buckminster Fuller in the 1930s, Otto similarly described efficiency as "doing more with less" (Fuller 1973 [1938], p. 259). In his work, Fuller pursued the goal of finding out an optimum development of geodesic domes based on a minimal use of material. Efficient and optimized forms can be obtained through a correct choice and development of material structures. These dictate which form can be developed.

From a different, yet complementary, perspective, Helmcke applied the same idea to biological form. In his studies of diatom shells, Helmcke pointed out that it was possible to "infer from the shape of diatom shells structure-forming processes" (Helmcke 1966, p. 8). Through the use of electron microscopes, he realized that it was possible to compare the structure-forming processes of diatom shells with those of chemistry. He found that some diatom shells have a strikingly regular pattern of points that appears to be composed of chambers. These chambers give the impression that, at the moment of shell formation, "small oil droplets lay close together

\footnotetext{
34 Stuttgart University Archives 138 (Sonderforschungsbereich 64: "Weitgespannte Flächentragwerke"), no. 3 .
} 
in a layer separated only by a thin proto-plasmatic layer into which the silica compounds were finally incorporated and transformed into a rigid structure" (Helmcke 1966, p. 13). Yet, the droplet-shaped chamber could be traced back to heterogeneous phases of a physico-chemical system. These were not confined to particular species or certain genera, but rather were generally valid. For example, this type of chamber could be found "in the same way in both the Centrales and the Pennales" (Helmcke 1966, p. 12). Thus, Helmcke concluded that "the slightest changes in the physicochemical balance of forces produce significant changes in the shell pattern. Theoretically, there is even the possibility that morphologically divergent forms are still related very closely." This morphogenetic principle was applicable to different diatoms, and it gave "an understanding that sometimes a particular structural element [Bauelement] may independently occur in species of several unrelated genera, while the same structural element [Bauelement] is absent from the related species of the genera in question" Helmcke 1966, p. 13).

As a result, Helmcke argued that organic form can be seen as the result of physical and chemical processes and not of genetic codes or natural selection. As he would put it in the late 1980s, "form is not only shaped by genetic programs and environmental modifications, but also by a third factor: the material-inherent design forces [den material-inhärenten Gestaltungskräften]" (Helmcke 1989, p. 135).

This was exactly the same idea Otto and Helmcke had popularized in their 1971 workshop on biology and building. As Otto pointed out:

The pressure of selection has produced highly effective forms in animals and plants. Using "lightweight construction", large forces can be transmitted with a low expenditure of mass. The capacity of any given object within organic and inorganic nature - in the macro and microcosms of biology or in technology and art - to transmit forces is dependent upon the form and the material. (Institut für Leichte Flächentragwerke 1971, p. 11; italics mine)

Hence, Otto and Helmcke developed a structural analysis of morphogenesis. According to this analysis, an efficient form is obtained by using as little material as possible, in line with the lightweight principle. Both organic and architectural form is then directed by its intrinsic physical and chemical forces. These constitute another essential morphogenetic mechanism. As Otto and colleagues would summarize their view in the 1979/1980 annual report of the SFB 64, "biology considers the principle of lightweight construction as one of the most important selection principles of living nature. Ultimately, living nature finds its shape with it. This happens also in technology. ... In addition to numerous other selection principles, it also follows the principle of lightweight construction." 35

\footnotetext{
35 Stuttgart University Archives 138 (Sonderforschungsbereich 64: "Weitgespannte Flächentragwerke"), no. 4.
} 


\section{Conclusion}

This article has discussed a dynamic group of scientists who actively investigated form properties during the 1950s and 1960s. They sought to investigate which factors control the genesis and transformation of organic forms. These scientists recognized that "the laws of geometry, natural materials, and growth processes give rise to patterns that are in some cases 'non-adaptive"” (Reif et al. 1985, p. 130). Thus, they contributed to expanding and critically re-elaborating the neo-Darwinian framework of evolutionary morphology.

Although Germans were at the forefront of uncovering form-structures not reducible to natural selection, they were certainly not the only scientists who were investigating the non-adaptive elements of forms. From different perspectives, English- and Italian-speaking scientists-including those focused on Rupert Riedl's investigations as well as biologists in the Netherlands-were also analyzing this topic. ${ }^{36}$ However, the German approach to form stands out because German biologists considered the whole range of aspects of their research focus. Moreover, they were able to attract financial resources and gained international recognition. For instance, Otto and Seilacher acquired financial support for a further Collaborative Research Center (SFB). The SFB 230 on "natural constructions" was established in 1984 with the precise idea of investigating the concept of form in biology and architecture. This legacy can still be found today in another SFB and two Clusters of Excellence recently funded in Germany. ${ }^{37}$

Their groundbreaking research was made possible by an intense exchange of practices, data, and knowledge between biological and non-biological disciplines and domains. In this process of knowledge transfer, new knowledge was created and continuously reshaped. As a result, evolutionary morphology was re-born and re-defined following its earlier alleged breakdown (Nyhart 1987; Allen 1975; Colemann 1980).

First, paleontologist Seilacher transferred the methods used in paleoichnology, a relatively marginal paleontological discipline, to the broader discussion of evolutionary biology at the end of the 1960s. By presenting his idea on form as the product of three interdependent factors ${ }^{38}$ he called attention to morphology's potential for

\footnotetext{
${ }^{36}$ On the relationship between these approaches, see Tamborini, The Architecture of Evolution: The Science of Form in Twentieth-Century Evolutionary Biology (under contract with University of Pittsburgh Press). On the English-speaking community, see Esposito (2017). On Riedl, see Wagner and Laubichler (2004), and for insights into the morphological research tradition in the Netherlands, see Dullemeijer (1974) and Love (2003).

${ }^{37}$ For instance, "the SFB-TRR 141, at least in the realm of architecture and structural engineering, is widely perceived as the successor of the famous 'SFB 230 - Natürliche Konstruktionen, Leichtbau in Architektur und Natur' funded by the DFG between 1984 and 1995 at the Universities of Stuttgart and Tübingen" (Knippers 2016, p. 7). The same can be said for the Clusters of Excellence, "Integrative Computational Design and Construction for Architecture," led by Achim Menges at the University of Stuttgart, and the Cluster of Excellence "Matters of Activity. Image Space Material," led by Wolfgang Schäffner at Humboldt University in Berlin.

${ }^{38}$ On the further development of Seilacher's triangle, see Briggs (2017), Reif et al. (1985), Seilacher and Gishlick (2014), and Briggs (2005).
} 
uncovering further evolutionary mechanisms. As a result, morphology was seen as an important discipline able to challenge, expand, and eventually extend the biological mechanisms theorized during the modern synthesis, ${ }^{39}$ as Gould and Lewontin indicated in their seminal paper (Gould and Lewontin 1979). Furthermore, Seilacher took part in the so-called "grounding meeting" of evolutionary developmental biology in 1981 (Bonner 1982). Thus, he ensured that prominent attention was given to the non-adaptive morphogenetic mechanisms uncovered during the $1960 \mathrm{~s} .{ }^{40}$

Second, a transfer of practices took place between biology and several prima facie non-biological disciplines. Biologists, architects, and engineers worked together to investigate structural elements of form. They shared practices, data, and viewpoints and set up collaborative research projects and centers. These provided the appropriate infrastructure through which knowledge could productively travel. Thanks to this infrastructure, the methods developed for specific biological objects and issues were transported into and applied to other knowledge domains and vice versa. As Seilacher stated, "this triple approach, called constructional morphology (Seilacher 1970), can be equally applied to the shapes of organisms or their parts, to animal products such as spider webs or burrow systems, or to human artifacts" (Seilacher 1973, p. 451). Similarly, Helmcke asserted that "the 'technical' and the 'living constructions' are so similar that both may be subsumed under a minimal theory" (Helmcke 1966, p. 13).

Consequently, in the 1950s and 1960s, evolutionary morphology became a fluid discipline. It acquired a new intra-disciplinary identity by overcoming its traditional disciplinary borders set in the late nineteenth century. Indeed, innovative morphological research was carried out by biologists, architects, and engineers who did not hold traditional professorships in evolutionary morphology: Helmcke had a professorship in biology and anthropology, Seilacher in paleontology, whereas Otto founded and directed the Institute for Lightweight Structures at the University of Stuttgart from 1964. ${ }^{41}$ They all used morphology to challenge narrow and dichotomist characterizations of evolutionary processes, mechanisms, and methods. As Weber had indeed suggested in the 1950s, morphologists needed to move beyond the methods proposed during the first half of the twentieth century. By doing so, they developed a holistic approach to the form problem and thus a new disciplinary identity. This synthetic approach enabled morphologists to expose structural elements that had been overlooked until then and could not be reduced to either natural selection or genetic programs. As a result, the form-finding analysis of the 1960s and 1970s became a valid alternative to both the idealistic and the mere descriptive morphology pursued in the first half of the twentieth century.

\footnotetext{
39 On the difference between expanding and extending the standard evolutionary theory, see (Love 2017).

40 On the so-called "Dahlem meeting," see Love (2015).

41 The list of outsiders can be expanded further. For instance, Wolfgang Gutmann worked at the Senckenberg Museum in Frankfurt. After his first polemical encounter with the traditional German morphological community, he was never again invited to other mainstream morphological symposia in Germany (see Gutmann and Weingarten 2003).
} 
This enterprise was not simply assisted, but rather made possible by a substantial use of technology. Morphologists not only employed a technical vocabulary (they equated form with natural manufacture or construction), but also paired their discipline with recent technological development. The renaissance of twentieth-century morphology was made possible by technological instruments such as the electron microscope and computers. The same use of this technology characterized both Raup's seminal work on morphospace and Seilacher's Konstruktionsmorphologie. ${ }^{42}$ Hence, twentieth-century morphologists understood that to unearth further morphogenetic mechanisms, the evolution of organic form should also be treated as a technical and engineering problem. ${ }^{43}$ They indeed implemented several practices and technologies aimed at technically controlling and reproducing morphogenetic processes.

This exchange of practices and knowledge, as well as the use of new technologies, entailed a reformulation of the notions of efficiency and optimality both in biology and architecture. The German approach to form presented in this article clearly departed from the notion of form as organic design developed by Pantin and Rudwick. While their concept was popularized by Gould's paper "Paleontology and the Science of Form" (Gould 1971a) and translated by Seilacher into German to be distributed at the 1971 Tübingen meeting, German scientists soon developed a different concept of form optimality. This did not emphasize the idea of mechanical fitness, as expressed by Gould and Rudwick during the late 1960s, but rather the concept of material plasticity and material internal dynamics. Therefore, German biologists attempted to transcend the classic machine-like character of organisms. This was the "central idea" of the science of form popularized by Gould during the 1960s up to mid-1970s (Gould 1971a, p. 61; Dresow 2017). Conversely, Seilacher, Otto, Helmcke, and their colleagues emphasized the functional properties of organisms, the importance of constraints as alternative evolutionary mechanisms, and downplayed the role of natural selection. Instead of adopting the classic machine-like character of organisms, German biologists saw organisms as complex and dynamic constructions. Furthermore, they set this new definition at the heart of the SFB 230, which was dedicated to "natural constructions."

Furthermore, in this paper I have shown how a German morphological tradition hostile to Neo-Darwinian mechanisms found its way to Gould and English-speaking biologists. I follow Max Dresow's recent work in identifying two distinct and quite opposite macroevolutionary syntheses in Gould's thought. While the early period of Gould's career (between 1966 and 1974) was characterized by his mechanical approach to the science of form, in the second phase (after 1977), Gould articulated "a new vision of macroevolution-one in which natural selection on organisms plays a markedly reduced role" (Dresow 2017. p. 25). As possible explanations for this shift, Dresow has pointed to the advent of hierarchy theory, including Steven Stanley's decoupling of macroevolution from microevolution, as well as Gould's aversion to sociobiology (ca. 1974-1977). In this paper, I have provided a further

42 On Raup's use of computers, see Sepkoski (2012, 2017), Tamborini (2019a).

43 See, for instance, Tamborini (2019a, 2019b). 
possible explanation: Gould's encounter with the methods, concepts, and results developed in Tübingen and Stuttgart. ${ }^{44}$ It is not a coincidence that in their very wellknown 1979 Spandrel paper, Gould and Lewontin would use the same argument against Rudwick's concept of morphology that Seilacher had made at the end of the 1960s. Seilacher criticized Rudwick's approach since it was centered merely on the power of natural selection. Moreover, the German paleontologist defined Rudwick's method as a "teleological way of looking" at biological form that overemphasized the adaptive meaning of organic forms (Seilacher 1967, p. 9). Gould and Lewontin would write almost the same critique ten years later (1979).

Hence, this article has presented German morphology as an alternative twentieth century evolutionary tradition that managed to sneak into an important debate in Anglophone biology and indirectly contribute to the formation of evo-devo. Thus, it has paved the way to a much broader comprehension of the shifts and movements that have shaped twentieth-century evolutionary biology. ${ }^{45}$

Acknowledgements Open Access funding provided by Projekt DEAL. I would like to thank David Sepkoski, Martin Rudwick, Alan Love, Mathias Gutmann, Derek Briggs, Max Dresow, Daniel Nicholson, and the two anonymous referees for their helpful suggestions on earlier versions of this paper. Many thanks also to Edith Seilacher, Frank Westphal, and Christian Assenbaum for the inspiring conversations we had on Konstruktionsmorphologie.

Open Access This article is licensed under a Creative Commons Attribution 4.0 International License, which permits use, sharing, adaptation, distribution and reproduction in any medium or format, as long as you give appropriate credit to the original author(s) and the source, provide a link to the Creative Commons licence, and indicate if changes were made. The images or other third party material in this article are included in the article's Creative Commons licence, unless indicated otherwise in a credit line to the material. If material is not included in the article's Creative Commons licence and your intended use is not permitted by statutory regulation or exceeds the permitted use, you will need to obtain permission directly from the copyright holder. To view a copy of this licence, visit http://creativecommons.org/licen ses/by/4.0/.

\section{References}

Allen, Garland E. 1975. Life Science in the Twentieth Century. New York: Wiley. Benninghoff, Alfred. 1935. Form und Funktion. Zeitschrift für die gesamte Naturwissenschaft 1: 36. Bock, Walter J. 1991. Explanations in Konstruktionsmorphologie and Evolutionary Morphology. In Constructional Morphology and Evolution, ed. N.V. Klaus Kittler-Schmidt, 9-29. Berlin: Springer.

\footnotetext{
44 Paleontologists Richard Fortey and Derek Briggs also acknowledged Seilacher's influence on Gould and Lewontin's critique of the adaptationist program. Fortey wrote, for instance, "in many ways, Seilacher anticipated the famous 1979 paper by Stephen J. Gould and Richard Lewontin, grandly titled: 'The Spandrels of San Marco and the Panglossian Paradigm: A Critique of the Adaptationist Programme', which is still widely cited. On a more down- to-earth level Seilacher produced case studies of many groups of organisms explaining how their designs worked in relation to habitat, and how the constructional tools available to the animal managed to build the necessary structures" (Fortey 2014, p. 545). Briggs expressed the same idea (2005, 2017).

45 See my book-length treatment of twentieth-century morphology, The Architecture of Evolution: The Science of Form in Twentieth-Century Evolutionary Biology (under contract with University of Pittsburgh Press).
} 
Bonner, John Tyler, ed. 1982. Evolution and Development. Report of the Dahlem Workshop on Evolution and Development Berlin 1981, May 10-15 Berlin: Springer

Briggs, Derek Ernest Gilmor, ed. 2005. Seilacher on the Science of Form and Function. Evolving Form and Function: Fossils and Development. Proceedings of a symposium honoring Adolf Seilacher for his contributions to paleontology, in celebration of his 80th birthday. (Special Publication of the Peabody Museum of Natural History). New Haven, CT: Yale University Press.

Briggs, Derek Ernest, and Gilmor. 2017. Seilacher, Konstruktions-Morphologie, Morphodynamics, and the Evolution of form. Journal of Experimental Biology Part B 328 (3): 197-206.

Colemann, William. 1980. Morphology in the Evolutionary Synthesis. In The Evolutionary Synthesis: Perspectives on the Unification of Biology, ed. : E. Mayr and W. B. Provine, 174-180. Cambridge, Mass.: Harvard University Press.

Dresow, Max W. 2017. Before Hierarchy: The Rise and Fall of Stephen Jay Gould's First Macroevolutionary Synthesis. History and philosophy of the life sciences 39 (2): 6.

Dresow, Max W. 2019. Macroevolution Evolving: Punctuated Equilibria and the Roots of Stephen Jay Gould's Second Macroevolutionary Synthesis. Studies in History and Philosophy of Science Part C: Studies in History and Philosophy of Biological and Biomedical Sciences 75: 15-23. https://doi. org/10.1016/j.shpsc.2019.01.003.

Dullemeijer, Pieter. 1974. Concepts and Approaches in Animal Morphology. Assen, The Netherlands: Van Gorcum.

Esposito, Maurizio. 2017. The Organismal Synthesis: Holistic Science and Developmental Evolution in the English-speaking World, 1915-1954. In The Darwinian Tradition in Context, ed. R.G. Delisle, 219-241. Heidelberg: Springer.

Fortey, Richard. 2014. Dolf Seilacher (1925-2014). Current Biology 24 (12): R544-R546.

Fuller, Richard Buckminster. 1973 (1938). Nine Chains to the Moon. London: Cape.

Gliboff, Sander. 2008. H.G. Bronn, Ernst Haeckel, and the Origins of German Darwinism. A Study in Translation and Transformation. Cambridge, Mass.: MIT Press.

Gould, Stephen Jay. 1971a. D'Arcy Thompson and the Science of Form. New Literary History 2 (2): 229-258.

Gould, Stephen Jay. 1971. Tübingen Meeting on Form. Journal of Paleontology 45: 1042-1043.

Gould, Stephen Jay, and Richard Lewontin. 1979. The Spandrels of San Marco and the Panglossian Paradigm-A Critique of the Adaptationist Program. Proceedings of the Royal Society B: Biological Sciences 205: 581-598.

Grene, Marjorie. 1958. Two Evolutionary Theories (I). The British Journal for the Philosophy of Science 9 (34): 110-127.

Gutmann, Mathias, and Michael Weingarten (eds.). 2003. Jahrbuch für Geschichte und Theorie der Biologie 9. Berlin: VWB-Verlag.

Günther, Klaus. 1949. Über Evolutionsfaktoren und die Bedeutung des Begriffs der „ökologischen Lizenz" für die Erklärung von Formenerscheinungen im Tierreich. In Ornithologie als biologische Wissenschaft (Festschrift Stresemann), Heidelberg: Winter Universiätsverlag.

Helmcke, Johann-Gerhard. 1966. Gedanken bei der Betrachtung von Diatomeenschalen im elektronenmikroskopischen Bild. Forschungen und Fortschritte 40 (1): 8-14.

Helmcke, Johann-Gerhard. 1989. Biologie und Bauen - Evolutionsprinzipien in natürlichen Strukturen und technischen Konstruktionen. In Evolution und Evolutionsstrategien in Biologie, Technik und Gesellschaft, ed. J. Albertz, 131-151. Wiesbaden: Akademie.

Helmcke, Johann-Gerhard, and Otto Frei. 1962. Lebende und technische Konstruktionen. Deutsche Bauzeitung 67 (11): 885-886.

Helmcke, Johann-Gerhard, and Willi Krieger. 1953-1977. Diatomeenschalen im elektronenmikroskopischen Bild. Teil 1-10. Berlin: Transmare-Photo.

Hertel, Heinrich. 1963. Struktur, Form, Bewegung. Mainz: Krausskopf.

Heumann, Ina, Holger Stoecker, Marco Tamborini, and Mareike Vennen. 2018. Dinosaurierfragmente: Zur Geschichte der Tendaguru-Expedition und ihrer Objekte, 1906-2017. Göttingen: Wallstein Verlag.

Institut für Leichte Flächentragwerke, ed. 1971. IL 3. Biologie und Bauen Teil 1. Information of the Institute for Lightweight Structures, University Stuttgart. Institut für leichte Flächentragwerke.

Institut für Leichte Flächentragwerke, ed. 1972. IL 4. Biologie und Bauen Teil 2. Information of the Institute for Lightweight Structures, University Stuttgart. Institut für leichte Flächentragwerke.

Institut für Leichte Flächentragwerke, ed. 1973. IL 6. Biologie und Bauen Teil 3. Information of the Institute for Lightweight Structures, University Stuttgart. Institut für leichte Flächentragwerke, Stuttgart. 
Keller, Sean. 2018. Automatic Architecture: Motivating Form After Modernism. Chicago, IL: University of Chicago Press.

Knippers, Jan. 2016. From Minimal Surfaces to Integrative Structures: The SFB-TRR 141 in the Light of the Legacy of Frei Otto and the SFB 230 'Natürliche Konstruktionen'. In Biomimetic Research for Architecture and Building Construction, eds. J. Knippers, K.G. Nickel, and T. Speck, 7-11. Cham, Switzerland: Springer.

Levit, Georgy S., Uwe Hossfeld, and Lennart Olsson. 2014. The Darwinian Revolution in Germany: From Evolutionary Morphology to the Modern Synthesis. Endeavour 30 (10): 268-278.

Levit, Georgy S., and Kay Meister. 2006. The History of Essentialism vs. Ernst Mayr's "Essentialism Story": A Case Study of German Idealistic Morphology. Theory in Biosciences 124 (3-4): 281-307.

Love, Alan. 2003. Evolutionary Morphology, Innovation, and the Synthesis of Evolutionary and Developmental Biology. Biology and Philosophy 18 (2): 309-345.

Love, Alan. 2015. Conceptual Change and Evolutionary Developmental Biology. In Conceptual Change in Biology. Scientific and Philosophical Perspectives on Evolution and Development, ed. Alan Love, 1-54. Heidelberg: Springer.

Love, Alan. 2017. Evo-devo and the Structure(s) of Evolutionary Theory: A Different Kind of Challenge. In Challenging the Modern Synthesis: Adaptation, Development, and Inheritance, eds. P.W. Huneman and M. Denis, 159-188. New York: Oxford University Press.

Maier, Gerhard. 2008. Zur morphologischen und phylogenetischen Methodologie von Hermann Weber The Morphological and Phylogenetic Methodology of Hermann Weber. Entomologia Generalis 31 (2): 113-117.

Meissner, I., and E. Möller. 2015. Frei Otto: Forschen, Bauen, Inspirieren. Munich: Detal.

Nyhart, Lynn K. 1987. The Disciplinary Breakdown of German Morphology, 1870-1900. Isis 78 (3): 365-389.

Nyhart, Lynn K. 1995. Biology Takes Form. Animal Morphology and the German Universities $1800-$ 1900. Chicago, IL: University of Chicago Press.

Olson, Everett C., and Robert L. Miller. 1958. Morphological Integration. Chicago, IL: University of Chicago Press.

Osgood, Richard G. 1975. The History of Invertebrate Ichnology. In The Study of Trace Fossils. A Synthesis of Principles, Problems and Procedures in Ichnology, ed. R. Frey, 3-12. Berlin: Springer.

Otto, Frei. 1971. Biology and Building. In Institut für Leichte Flächentragwerke (ed) IL 3. Biologie und Bauen Teil 1. Information of the Institute for Lightweight Structures, University Stuttgart, 6-22. Stuttgart: Institut für leichte Flächentragwerke.

Otto, Frei, Irene Meissner, Rainer Barthel, and Christian Brensing (eds.). 2005. Frei Otto. Complete Works: Lightweight Construction, Natural Design. Basel: Birkhäuser.

Otto, F., G. Vrachliotis, J. Kleinmanns, M. Kunz, and P. Kurz (eds.). 2017. Frei Otto: Thinking by Modeling. Leipzig: Spector Books.

Pantin, Carl F.A. 1951. Organic Design. Advancement of Science 30: 138-150.

Princehouse, Patricia Maria. 2003. Mutant Phoenix: Macroevolution in Twentieth-century Debates Over Synthesis and Punctuated Equilibrium. PhD dissertation: Harvard University.

Raup, David M. 1961. The Geometry of Coiling in Gastropods. Proceedings of the National Academy of Sciences 47 (4): 602-609.

Raup, David M. 1962. Computer as Aid in Describing Form in Gastropod Shells. Science 138 (3537): $150-152$.

Raup, David M. 1972. Approches to Morphologic Analysis. In Models in Paleobiology, ed. T. J. M. Schopf, 28-44. San Francisco: Freeman, Cooper \& Co.

Raup, David M. 1966. Geometric Analysis of Shell Coiling: General Problems. Journal of Paleontology 40: $1178-1190$.

Raup, David M. 1969. Computer as a Research Tool in Paleontology. In Computer Applications in the Earth Sciences: An International Symposium, ed. F.M. Daniel, 189-204. New York: Plenum Press.

Raup, David M., and Arnold Michelson. 1965. Theoretical Morphology of the Coiled Shell. Science 147 (3663): 1294-1295.

Raup, David M., and Adolf Seilacher. 1969. Fossil Foraging Behavior: Computer Simulation. Science 166 (3908): 994-995.

Reif, Wolf-Ernst. 1985. Konstruktionsmorphologie als biologisches Arbeitskonzept bei Hermann Weber. Aufsätze und Reden der Senckenbergischen Naturforschenden Gesellschaft 35: 133-142. 
Reif, Wolf-Ernst. 1983. Evolutionary Theory in German Paleontology. In Dimensions of Darwinism: Themes and Counterthemes in Twentieth-Century Evolutionary Theory, ed. Marjorie Grene, 173203. Cambridge: Cambridge University Press.

Reif, Wolf-Ernst. 1986. The Search for a Macroevolutionary Theory in German Paleontology. Journal of the History of Biology 19 (1): 79-130.

Reif, Wolf-Ernst, Roger D.K. Thomas, and Martin S. Fischer. 1985. Constructional Morphology: The Analysis of Constraints in Evolution. Dedicated to A. Seilacher in Honour of his 60 Birthday. Acta Biotheoretica 34: 233-248.

Reif, Wolf-Ernst. 1993. Afterword. In Otto Schindewolf, Basic Questions in Paleontology: Geologic Time, Organic Evolution, and Biological Systematics. Chicago, IL: University of Chicago Press.

Remane, Adolf. 1952. Die Grundlagen des natürlichen Systems der vergleichenden Anatomie und der Phylogenetik, vol. 1. Leipzig: Akademische Verlagsgesellschaft.

Remane, Adolf. 1955. Morphologie als Homologieforschung. Verhandlungen der Deutschen Zoologischen Gesellschaft 1954 18: 159-183.

Richards, Robert J. 2002. The Romantic Conception of Life: Science and Philosophy in the Age of Goethe. Chicago, IL: University of Chicago Press.

Richards, Robert J. 2008. The Tragic Sense of Life. Ernst Haeckel and the Struggle over Evolutionary Thought. Chicago, IL: University of Chicago Press.

Richter, Rudolf. 1927. Die fossilen Fährten und Bauten der Würmer. Paläontologische Zeitschrift 9 (1-3): 193-240.

Richter, Stefan. 2016. Peter Ax's View on Homology-A Comparison with Remane and Hennig. Peckiana 11: 67-75.

Rieppel, Olivier. 2016. Phylogenetic Systematics: Haeckel to Hennig. London: CRC Press.

Rudwick, Martin. 1964. The Inference of Function from Structure in Fossils. The British Journal for the Philosophy of Science 15 (57): 27-40.

Rudwick, Martin. 2017. The Fate of the Method of "Paradigms" in Paleobiology. Journal of the History of Biology 51 (3): 479-533.

Rudwick, Martin. 2018. Functional Morphology in Paleobiology: Origins of the Method of "Paradigms". Journal of the History of Biology 51 (1): 135-178.

Schäfer, Wilhelm. 1937. Bau, Entwicklung und Farbenentstehung bei den Flitterzellen von Sepia officinalis. Zeitschrift für Zellforschung und Mikroskopische Anatomie 27 (2): 222-245.

Schindewolf, Otto H. 1936. Palaeontologie, Entwicklungslehre und Genetik: Kritik und Synthese. Berlin: Borntraeger.

Schindewolf, Otto H. 1950. Der Zeitfaktor in Geologie und Paläontologie. Stuttgart: E. Schweizerbart'sche.

Schindewolf, Otto H. 1964. Erdgeschichte und Weltgeschichte. In: Akademie der Wissenschaften und der Literatur Mainz. Abhandlungen der mathematisch-naturwissenschaftlichen Klasse. 53-104.

Schindewolf, Otto H. 1993. Basic Questions in Paleontology: Geologic Time, Organic Evolution, and Biological Systematics. Chicago, IL: University of Chicago Press.

Schopf, Thomas J.M. (ed.). 1972. Models in Paleobiology. San Francisco: Freeman, Cooper \& Co.

Seilacher, Adolf, and A.D. Gishlick. 2014. Morphodynamics. London: CRC Press.

Seilacher, Adolf. 1951a. Zur Einteilung und Deutung fossiler Lebensspuren. PhD Dissertation. Eberhard Karls Universität Tübingen.

Seilacher, Adolf. 1951b. Der Röhrenbau von Lanice conchilega (Polychaeta): Ein Beitrag zur Deutung fossiler Lebensspuren. Senckenbergiana Maritima: wissenschaftliche Mitteilungen der Senckenbergischen naturforschenden Gesellschaft (1-4).

Seilacher, Adolf. 1953. Studien zur palichnologie. I. Uber die methoden der palichnologie. Neues Jahrbuch fur Geologie und Palaontologie, Abhandlungen 96: 421-452.

Seilacher, Adolf. 1953. Studien zur Palichnologie. II. Die fossilen Ruhespuren (Cubichnia). Neues Jahrbuch für Geologie und Paläontologie. Abhand 98: 87-124.

Seilacher, Adolf. 1960. Lebensspuren als Leitfossilien. Geologische Rundschau 49 (1): 41-50.

Seilacher, Adolf. 1967. Fossil behavior. Scientific American 217 (2): 72-83.

Seilacher, Adolf. 1970. Arbeitskonzept zur Konstruktions-Morphologie. Lethaia 3: 393-396.

Seilacher, Adolf. 1973. Fabricational Noise in Adaptive Morphology. Systematic Zoology 22 (4): 451-465.

Sepkoski, David. 2012. Rereading the Fossil Record: The Growth of Paleobiology as an Evolutionary Discipline. Chicago, IL: University of Chicago Press.

Sepkoski, David. 2017. The Database Before the Computer? Osiris 32 (1): 175-201. 
Tamborini, Marco. 2015. Paleontology and Darwin's Theory of Evolution: The Subversive Role of Statistics at the End of the 19th Century. Journal of the History of Biology 48 (4): 575-612.

Tamborini, Marco. 2016. "If the Americans Can Do It, So Can We": How Dinosaur Bones Shaped German Paleontology. History of Science 54 (3): 225-256.

Tamborini, Marco. 2017. The Reception of Darwin in Late Nineteenth-Century German Paleontology as a Case of Pyrrhic Victory. Studies in History and Philosophy of Biological and Biomedical Sciences 66: 37-45.

Tamborini, Marco. 2019. Umwelt und organische Form: Technowissenschaftlicher Zugang zur Historizität der Evolution. In Jahrbuch der Technikphilosophie 2019, ed. A. Friedrich, P. Gehring, C. Hubig, A. Kaminski, and A. Nordmann, 122-145. Baden-Baden: Nomos.

Tamborini, Marco. 2019. Series of Forms, Visual Techniques, and Quantitative Devices: Ordering the World between the End of the 19th and Early 20th Centuries. History and Philosophy of the Life Sciences 41: 49. https://doi.org/10.1007/s40656-019-0282-x.

Tamborini, Marco. 2020. Technoscientific Approaches to Deep Time. Studies in History and Philosophy of Science Part A 79: 57-67. https://doi.org/10.1016/j.shpsa.2019.03.002.

Wagner, Günter P., and Manfred D. Laubichler. 2004. Rupert Riedl and the Re-synthesis of Evolutionary and Developmental Biology: Body Plans and Evolvability. Journal of Experimental Zoology Part B: Molecular and Developmental Evolution 302 (1): 92-102.

Weber, Hermann. 1950/1951. Skriptum zur Vorlesung "Einführung in die Terminologie und Methode der Konstruktionsmorphologie." Partially reproduced in Reif 1985.

Weber, Hermann. 1954. Stellung und Aufgaben der Morphologie in der Zoologie der Gegenwart. Zoologischer Anzeiger Suppl: 137-159.

Weber, Hermann. 1958. Konstruktionsmorphologie. Zoologischen Jahrbücher 68: 1-112.

Publisher's Note Springer Nature remains neutral with regard to jurisdictional claims in published maps and institutional affiliations. 